\title{
“HALF A LOAF IS BETTER THAN NOTHING": THE RISKS AND RESILIENCE OF DAY LABOURERS IN CAPE TOWN
}

\author{
Professor Mapendere, Catherina Schenck, Derick Blaauw
}

Professor Mapendere ORCiD id: 000-0002-4418-2577

Catherina Schenck ORCiD id: 0000-0001-5299-5355

Derick Blaauw ORCiD id: 0000-0001-8750-4946

Mr Professor Mapendere, Postgraduate student, Department of Social Work, University of the Western Cape, South Africa.

Professor Catherina Schenck, DST/NRF/CSIR Chair in Waste and Society, University of the Western Cape, South Africa.

Professor Derick Blaauw, School of Economic Sciences, North-West University, Potchefstroom, South Africa.

Keywords: day labour, unemployment, poverty, resilience, risks, informal economy

\section{INTRODUCTION}

According to Worthington and Scherer (2004), resilience is the process of adapting well in the face of adversity, trauma, tragedy, threats or other significant sources of stress. The concept of resilience draws upon previous work in the area of psychology in which resilience is conceptualised not as an individual trait or characteristic, but as a dynamic process in the lives of people who encounter adversity or significant hardships (Van Breda, 2018; Walker, Anderies, Kinzig \& Ryan, 2006).

Similarly, in Van Breda's (2018) critical review of the concept resilience, he widens the scope or definition to incorporate both the process and outcomes components. Van Breda (2018) views resilience as "multilevel processes that systems engage in to obtain better-than-expected outcomes in the face or wake of adversity". This implies that people are seen as resilient when they respond better than expected in dealing with adversity. These 'multilevel' processes not only occur in the individual but also in the context of the person, which explains that there can be different pathways to resilience, depending on the unique person and his or her context. People do not respond the same way to the same adverse experience. A different pathway is referred to by Van Breda (2018) as distal-onset chronic adversity, which involves coping in the face of the adversity while it is on-going. This helps to explain how people can respond better than expected under continuous adverse circumstances such as chronic poverty and unemployment. It is in terms of this view of resilience that the risks and resilience of the day labourers at a hiring site in Parow in Cape Town were explored to understand what kind of adversity they face on a daily basis and how they deal with the difficulties on a daily basis. The results of the study will also provide direction to the social workers responses toward vulnerable groups.

The term 'day labourers' refers to the unemployed, usually men, who gather on sidewalks, parking lots, near building supply stores or other locations, which enables them to be visible to potential employers, waiting to be hired for a day's employment (Blaauw, Pretorius, Schoeman, \& Schenck, 2012).

Day labouring is a form of informal employment. Although these workers sometimes work in the formal sector, they do so on a casual basis. Contingent working arrangements are commonplace in the United States and other parts of the world as companies, by employing casual workers, reduce the cost of inputs and increase production (Peck \& Theodore, 2001).

Standing daily on the open street corner in the rain, when it is bitterly hot or cold, with no certainty of even getting work at all pose its own risks on numerous social and economic levels.

As the number of sites at which day labourers gather to wait the arrival of prospective employers has increased, more interactions with the owners of nearby businesses and local residents are taking place, 
some of which entail conflicts (Blaauw et al., 2012). Although these conflicts contribute to the risks to which the day labourers are exposed every day (Blaauw, Louw \& Schenck, 2006), the stoical persistence which they demonstrate by standing at hiring sites such as street corners every day provides compelling testimony to their resilience. In addition, a significant number of day labourers in Cape Town are foreign nationals who, like their South African counterparts, are the sole breadwinners in their families (Malinga, 2015). Malinga (2015) explains that as a result of significantly diminished opportunities for employment in their home countries, often owing to political strife and turmoil, people are obliged to migrate to other countries in search of employment. Sterken (2010) and Blaauw, Pretorius and Schenck (2016) found that the ranks of day labourers in Cape Town were comprised not only of South African-born men, but also many immigrants, with Zimbabweans being particularly strongly represented.

Studies by Blaauw et al. (2006) and Blaauw (2010) provide indications that the apparent resilience of day labourers in South Africa could possibly be partially explained by the extent to which their families are financially dependent upon them, but no study so far has specifically explored the resilience of the day labourers. To date, most studies which have been conducted on day labourers in South Africa have endeavoured to describe their socioeconomic conditions (Blaauw et al., 2006; Blaauw, 2010). To the best of the knowledge of the researchers, this study is the first which has been conducted to investigate the risks to which day labourers are exposed to in Cape Town in South Africa, and the resilience which they display in the face of identified risks.

Day labourers constitute a highly marginalised population, with many people having limited options for employment owing to outsourcing, the closures of factories and businesses, discrimination in the workplace, and immigrant status (International Labour Organisation (ILO), 2005). As day labourers are informal workers, in most cases they are also socially excluded from the benefits which societies extend to their citizens, such as access to appropriate social services and opportunities for employment and decent incomes. The constant fear of deportation among immigrants often provides supervisors and employers with the means to exploit desperately poor foreign workers and to intimidate them into accepting many types of abuse. The findings of Blaauw et al. (2006) and Blaauw (2010), who conducted extensive research into the phenomenon of day labouring in South Africa, have revealed several instances of abusive treatment of day labourers by employers. Abuses have included failing to pay employees, denying them breaks during their working days, and requiring them to work in unsafe conditions, thereby exposing them to significantly increased risks of sustaining work-related injuries.

The study was conducted to obtain an understanding of the nature of the risks which day labourers are experiencing, and the resilience which they displayed in the face of the hardships which they encountered. The findings from research by Theodore, Blaauw, Schenck, Valenzuela, Schoeman \& Meléndez, (2015) in the United States also revealed that the risks to which day labourers are exposed to include exploitation by employers, the effects of being away from their families, living a harsh life on the streets, and unfavourable living conditions in poor and run-down neighbourhoods. Conversely, Blaauw (2010) in South Africa revealed that employers tended to require day labourers to work for longer hours without breaks than workers in formal employment and to pay them considerably less. Theodore, Pretorius, Blaauw and Schenck. (2018) found that the foreign day labourers, in particular, have limited access to facilities such as healthcare and the ability to exercise basic human rights such as to protection by the police, mainly owing to a lack of relevant legal documents. The foreigners in particular experiences risks related to food security, housing and xenophobia. It is against the backdrop of these realities that the authors endeavoured to assess and evaluate the risks to which the day labourers at a particular hiring site in Cape Town were exposed to and the resilience which they displayed by listening to their voices.

This article gives attention to the factors which contribute to the hardships which day labourers in South Africa endure and the risks to which they are exposed, along with the ways in which they are stigmatised and subjected to discrimination. Meaningful insights into the lives of day labourers could be instrumental in creating an awareness of their vulnerability and the adoption of a developmental and 
transformational social welfare approach (Taylor and Triegaardt 2018) to the day labour market, its management and the broader informal sector they are part of. The basis for developmental and transformational social welfare is social justice and human rights which should address inequalities, discrimination and multiple deprivations people experience. Blaauw et al (2017) made a call to social work and social service professional to give attention to the vulnerabilities of informal workers. The research question we tried to answer was: What are the risks which day labourers at a hiring site in Cape Town are exposed to and how is the resilience which they display manifested?

\section{RESEARCH METHODOLOGY}

The research adopted an ethnographic research design and made use of both qualitative and quantitative research methods. Ethnography is the study of people in their own environments through the use of methods such as participant observation and conducting interviews with individual participants or groups of participants (Babbie and Mouton, 2010). Ethnographic research is field-based in that it is conducted in the settings in which people actually live, work and function. Hoey (2014) maintains that ethnography can be equated with virtually any qualitative research project whose intent is to provide a detailed, in-depth description of everyday life and practice. Geertz (1973) uses the term 'thick description' to describe the detailed and in-depth descriptive data which qualitative research methods yield. Ethnographic research designs allow for a great deal of flexibility, as they do not require extensive pre-fieldwork designing and allow for changes which occur during the conducting of the research (Hammersley \& Atkinson, 1983).

The data were collected through the use of a variety of research methods, such as observations and individual and group interviews with day labourers and other people, such as members of local communities, owners and employees of formal and informal businesses near the hiring site, and employers of day labourers, until the point of saturation was reached and no new data were generated.

The research study was conducted at a day labour hiring site in Parow, Cape Town, at which an estimated 50 day labourers gathered each morning. The study used purposive convenience sampling to select the research sample at the site. During April of 2017, the quantitative part of the study was completed as part of the National Day Labour Study in Cape Town. The hiring site in Parow was then selected for the qualitative part of the study. The site and the participants were selected on the basis of the following criteria:

- Both foreign and local South African day labourers should be involved;

- There should be a minimum of 50 day labourers at the site each day;

- The day labourers who were interviewed should be over the age of 18 years.

The data were gathered from questionnaires, semi-structured interviews and direct observations. The following research methods and instruments were used to collect the data:

- A questionnaire which enabled the researcher to gather data pertaining to the socioeconomic backgrounds of the day labourers;

- Recorded semi-structured interviews with day labourers, owners of local businesses and prospective employers;

- Recorded focus group discussions to gather in-depth qualitative data concerning the risks to which the day labourers are exposed and the resilience which they display;

- Observations: The researcher made field notes at the hiring site to record the interactions of the day labourers with one another, employers, owners of local businesses, and local residents.

The qualitative data were analysed by means of thematic analysis as described by Braun and Clarke (2006). De Vos, Strydom, Fouche and Delport (2011) explain that the analysis of qualitative data refers to the categorisation, ordering and summarising of data to obtain answers to research questions. The 
quantitative data were captured using MS Excel software and analysed by means of the SPSS software package.

It was necessary for the researcher to go to the hiring site early each morning to meet potential participants in order to engage with them before prospective employers arrived. In each instance the researcher introduced himself and explained the purpose of the study prior to conducting the interview. In the cases of participants who were not available to be interviewed owing to having been hired, alternative arrangements were made and the interviews were conducted at more convenient times.

In order to ensure that the participants were adequately informed concerning the purpose of the study and aware that their participation was strictly voluntary, they were required to sign a consent form. The consent form was available in English, Xhosa and Afrikaans but all completed the English consent form. For those not being literate, the content of the consent form was explained and they could sign their names or with a cross. Before the commencement of the interviews, the interviewees were informed that he would be free to terminate the interview if a potential employer appears. No remuneration was offered to the respondents for their participation for the mere reason that it will expose fieldworkers to possible criminal activities if they were to be on the street with cash. In addition the researchers wanted the day labourers to participate freely and not being coerced to participate. Appreciation was expressed for participating in the study. All of the qualitative interviews were completed for 24 day labourers at the chosen site.

Group interviews were also conducted on the street corner on which the hiring site was located. The participants in the group interviews were invited to speak, but also to give other members opportunities to speak. Although the first author was born in Zimbabwe, as he has resided in South Africa for a long time, he is able to speak and understand isiXhosa. As some of the participants were not fluent in English, the researcher was obliged to converse with them in isiXhosa, which put them at ease. The interviews with the foreigners were conducted in Shona and English, depending on their preference. Being from Zimbabwe, the first author is fluent in both. The interviews were subsequently translated into English.

Primary quantitative data were collected through the administration of a questionnaire, a permissible means of gathering data in ethnographic studies (Bless, Higson-Smith \& Hagee, 2006). The design of the questionnaire was informed by the format which was used in the studies conducted by Blaauw (2010) and Blaauw et al. (2016); Blaauw, Schenck, Pretorius \& Schoeman 2017). It was decided to incorporate a questionnaire into the study because it was deemed to provide the most suitable method for generating primary data to describe the demographic and socio-economic position of the research population and to provide data in the same form for all respondents (Louw, 2007; Blaauw, 2010).

Two types of observations are practised in qualitative research, namely, simple observation and participant observation (Babbie \& Mouton, 2008:293). This study used simple observation. In simple observations the researchers are positioned outside of the field in which they are interested, whereas in participant observation the researcher becomes a member of the group which he or she is studying. In this study observation was used to collect non-verbal data such as information pertaining to the environment, the actions of participants, physical characteristics and non-verbal communication. The first author went to the hiring site each day and spent a great deal of time among the day labourers, observing their day-to-day activities. He paid careful attention to how they presented themselves to prospective employers and endeavoured to adopt their patois, in order to gain their trust, reduce suspicion and increase their willingness to divulge information.

The research project was approved by the Senate Research and Ethics committee of the University of the Western Cape1.

1 The Senate Research ethics committee number HS/18/2/4 


\section{RESULTS}

\section{The community in which the hiring site is located and observations by the researcher}

The hiring site is in front of a building supply store in Parow in Cape Town. The site is on the corner of a busy road, which makes the day labourers highly visible and provides easy access for prospective employers.

One of the criteria for the selection of the site was the presence of both South Africans and foreigners. Only South Africans and Zimbabweans were present at the hiring site. From the onset it was clear that Zimbabweans and South Africans at the site were strictly segregated. Zimbabweans stood on one side of the road while their South African counterparts stood on the other. As the members of each group were unwilling to participate in group interviews with members of the other, it was necessary to interview each group separately.

When the vehicle of a prospective employer stopped at the site, day labourers rushed to arrive first at the vehicle. The negotiations were very quick and most questions did not concern remuneration, but rather the type of work which needed to be done and whether the day labourers possessed the skills which the prospective employer required. The first person to interact with a prospective employer had a higher likelihood of being employed for the day than the others if he had the skills which the work required. The researcher also observed that language played a role in obtaining employment. Day labourers who could not communicate well in English were often unlikely to be employed in these instances. The hiring site appeared to attract only men, as the researcher observed no women at the site during the period that the study was conducted.

\section{Demographic profile of the participants}

The ages of the participants ranged from 20 to 60 years. Of the 24 day labourers interviewed, $41.6 \%$ (10) fell into the age range between 36 to 45 years. The youth group between 20 to 35 years of age was also $41,6 \%$, while the remainder (16,8 comprised of older men who were from 46 to 60 years of age. Owing to the strenuous nature of most types day labour work, being young and physically strong provides individual workers with definite competitive advantages in terms of securing informal employment for the day (Blaauw 2010).

Similar to previous studies on the day labourers, only (Blaauw 2010, Blaauw et al., 2017, Theodore et al., 2018) only $16,8 \%$ of the participants completed secondary school Some of the participants indicated that they had qualifications beyond school, but they had been obliged to work as day labourers owing to a lack of opportunities for employment in the formal and informal sector.

"I can do any job, but l am a qualified carpenter. So, if a person comes and wants someone who can do gardening, l go, because l need money."

Confirming the above findings, the national study by Blaauw (2010) revealed that levels of relevant skills and educational qualifications among day labourers were generally low. Consequently, low levels of schooling leave the people who gravitate towards the day labour market vulnerable and excluded from the formal labour market. In addition, it emerged that the participants had not had adequate safety networks in their communities or families which could provide them with support to complete school. They had been vulnerable as children and had no means of escaping from living conditions characterised by abject poverty. The vulnerability of the day labourers as children were evident in the reasons they gave why they left school and which prevent them from completing school as described in Table 1.

\section{TABLE 1}

\section{REASONS FOR LEAVING SCHOOL / THERE WAS NO MONEY SO HE HAD TO GO} LOOK FOR WORK

Had to work for siblings 


\begin{tabular}{|l|} 
I ran away \\
\hline Was forced to leave school to herd cattle \\
\hline No money for school fees \\
\hline Parents deceased. Had to support younger siblings \\
\hline Parents deceased. Discouraged by the circumstances \\
\hline No money to continue schooling \\
\hline
\end{tabular}

Source: Research data

The demographic data further showed that the majority $(70.8 \%)$ of the participants were South Africans, while the remainder $(29,2 \%)$ came from Zimbabwe. The findings of a national study which was conducted by Blaauw (2010) and Kok, Cross, and Rowe (2010), revealed that South Africans accounted for $86 \%$ of their overall research sample while the remaining $14 \%$ were foreign workers. The findings confirmed the growing numbers of foreign born day labourers since the studies of day labourers by Blaauw (2010) in South Africa where foreign workers comprised less than $10 \%$ of the sample of 3830 day labourers in that study. One of the reasons for the ever increasing migration of Zimbabweans to South Africa is the deteriorating socio-political and economic circumstances in Zimbabwe, especially since 2008 when the Blaauw (2010) study was completed (Blaauw et al., 2017).

Most of the South Africans were IsiXhosa-speaking and originate from the Eastern Cape Province. They are effectively also migrants who in-migrated from the Eastern Cape to the Western Cape Province in search for work. Only three of the participants indicated that Afrikaans was their home language and that they originate from the Western Cape Province.

The findings further revealed that only $16 \%$ of the participants were married and a further $13 \%$ were cohabiting with partners. A significant majority of 50\% were single and had never been married, $16 \%$ were either separated or divorced, and $4 \%$ were widowed. Trimble and Fisher (2006) maintain that the high percentages of unmarried day labourers might be indicative of their 'dislocation' from family life and the difficulty which they experienced in forming and maintaining relationships. The participants described a variety of family problems which had acted as push and pull factors for their entry into the day labour market. Most prominent among the problems which they cited had been their inability to pay lobola ${ }^{2}$ in order to marry, as their culture and customs demand (Malinga 2015).

The next section will highlight the themes and subthemes which emerge from the research findings, highlighting the risks and resilience factors manifested by the participants.

2 Lobola refers to the prospective husband or head of his family paying in cash or kind the head of the prospective bride's family in customary marriages. 
Themes and subthemes

TABLE 2

SUMMARY OF THE THEMES AND SUB-THEMES WHICH EMERGED FROM THE THEMATIC ANALYSIS

\begin{tabular}{|c|c|}
\hline THEMES & SUB-THEMES \\
\hline $\begin{array}{l}\text { Theme 1: The risks to which day labourers are } \\
\text { exposed in relation to obtaining employment } \\
\text { and generating income }\end{array}$ & $\begin{array}{l}\text { - A lack of sufficiently regular employment } \\
\text { - Factors and considerations which motivated the } \\
\text { participants to continue to try to obtain employment as } \\
\text { day labourers }\end{array}$ \\
\hline $\begin{array}{l}\text { Theme 2: Forms of discrimination to which } \\
\text { day labourers are subjected }\end{array}$ & $\begin{array}{l}\text { - Discrimination among themselves } \\
\text { - Discrimination at the hands of employers }\end{array}$ \\
\hline $\begin{array}{l}\text { Theme 3: The risks which the working } \\
\text { conditions of day labourers entail }\end{array}$ & \\
\hline $\begin{array}{l}\text { Theme 4: The risks to which day labourers are } \\
\text { exposed in relation to inconsistent earnings } \\
\text { and non-payment of wages }\end{array}$ & \\
\hline $\begin{array}{l}\text { Theme 5: The resilience which day labourers } \\
\text { display }\end{array}$ & $\begin{array}{l}\text { - Resilience in the form of mutual support } \\
\text { - Resilience owing to support received from other } \\
\text { people }\end{array}$ \\
\hline
\end{tabular}

Theme 1: The risks to which day labourers are exposed in relation to obtaining employment and generating income

\section{Sub-theme 1: A lack of sufficient regular employment and income}

Erdogan and Bauer (2009) explain that the adjective 'insufficient' denotes a lack of something which is either necessary or required. The participants complained that their inability to find sufficiently regular formal and informal employment represented the defining characteristic of their daily lives as day labourers.

The data from the questionnaires confirmed the lack of access to sufficient work and income as they were asked to indicate the days they had been able to access work during the previous week.

This is captured in Table 3. 
TABLE 3

DAYS THE DAY LABOURERS ACCESSED WORK DURING THE PREVIOUS WEEK OF THE INTERVIEW

\begin{tabular}{|c|c|c|c|c|c|c|c|}
\hline $\begin{array}{l}\text { Day } \\
\text { labourer }\end{array}$ & Day 1 & Day 2 & Day 3 & Day 4 & Day 5 & Day 6 & Day 7 \\
\hline \multicolumn{8}{|l|}{1} \\
\hline \multicolumn{8}{|l|}{2} \\
\hline 3 & & & Painting & Painting & Painting & & \\
\hline \multicolumn{8}{|l|}{4} \\
\hline 5 & & Dirt removal & & & & & \\
\hline 6 & Tiling & & & Gardening & Gardening & $\begin{array}{l}\text { Mixing } \\
\text { concrete }\end{array}$ & \\
\hline 7 & & & & & & Tiling & \\
\hline \multicolumn{8}{|l|}{8} \\
\hline 9 & & Plastering & Plastering & & & Bricklaying & Plastering \\
\hline \multicolumn{8}{|l|}{10} \\
\hline \multicolumn{8}{|l|}{11} \\
\hline \multicolumn{8}{|l|}{12} \\
\hline 13 & & Tiling & Tiling & & & & \\
\hline \multicolumn{8}{|l|}{14} \\
\hline 15 & $\begin{array}{l}\text { Chopping } \\
\text { wood }\end{array}$ & $\begin{array}{l}\text { Chopping } \\
\text { wood }\end{array}$ & & & & & \\
\hline 16 & Paving & Paving & Paving & Paving & Paving & Paving & Paving \\
\hline \multicolumn{8}{|l|}{17} \\
\hline \multicolumn{8}{|l|}{18} \\
\hline \multicolumn{8}{|l|}{19} \\
\hline \multicolumn{8}{|l|}{20} \\
\hline \multicolumn{8}{|l|}{21} \\
\hline 22 & Carpentry & Carpentry & Carpentry & Carpentry & & & Carpentry \\
\hline 23 & Plumbing & Plumbing & & & Plumbing & & \\
\hline 24 & $\begin{array}{l}\text { Painting } \\
\text { facia boards }\end{array}$ & $\begin{array}{l}\text { Painting } \\
\text { facia boards }\end{array}$ & $\begin{array}{l}\text { Painting } \\
\text { facia boards }\end{array}$ & $\begin{array}{l}\text { Painting facia } \\
\text { boards }\end{array}$ & Plastering & & \\
\hline
\end{tabular}

Source: Research data

The data from Table 2 show that $50 \%$ (12) of the day labourers were not able to access any work and income for the whole week prior to the day of the interview. Only one was employed for the entire week to do paving. Two were employed for five days, two for four days, two for three days, two for two days and two for one day.

The findings of the study in South Afric conducted in South Africa by Kok et al. (2010) revealed that the day labourers in their research sample spent an average of 5 days a week standing at street corners, business parks and traffic lights in order to find work. In this study the average number of days the workers were standing in the hope of accessing work was 6 days. Almost half of the respondent in this study indicated that they went to the hiring site for 7 days a week as the hardware shop in front of which they stand is open for 7 days a week. Their desperate need to obtain employment and income was quite evident when it was explored how long it took for the day labourers to get to the hiring site. This will be illustrated with a case description:

- The day labourer is from the Eastern Cape, 37 years of age, single, looks after his uncle and one of the few who completed his secondary schooling3. Since the completion of school he stands as a day

3 Completion of secondary school is also referred to as $\mathrm{Gr} 12$ or Matric 
labourer. He currently leaves home in Khayelitsha at 3:45 in the morning to be at the site at 5:45(2 hours). He leaves the site at 17:00. He comes to the site 7 days per week and was employed for 4 days the previous week before the interview. He claim

- Another participant age 22 with who completed his secondary schooling, shared that he spent up to 90 minutes (1hour $30 \mathrm{~min}$ ) to get to the hiring site. He resides in the suburb Retreat in Cape Town and reported that he needed to take a train from Retreat to Cape Town, another train from Cape Town to Parow, and then a taxi to the hiring site. The week before the interview he was one of the unlucky day labourers who did not manage to access any work and income for the week.

- The day labourer who spent the shortest period of time walking or by using public transport, to get to the hiring site was 30 minutes. If they do not have transport money to get home they will sleep rough.

If they are not able to obtain employment every day, their ability to survive is severely jeopardised, particularly in the cases of those who support families or dependants. The findings from the questionnaire revealed that on average participants support 4,3 persons ranging between 0-10 dependants. One day labourer is supporting 10 people which obliged him go to the site as often as 7 days a week, in the hope that he will be able to access employment and an income. Two day labourers provide the following description:

"I struggle, my brother, because we struggle to get that money that is little, for me to pay rent here and to buy my food. It is very difficult ... sometimes I get that little money I have, I just make a quarter of it and give it to my family, other times I will try to pay my rent, thinking that maybe something can happen tomorrow, you see."

Living on hope that they may get employment is one of the driving forces to be at the site daily. Another driving force was expressed as the need to care for the family they are responsible for:

"It is very tough. It is very difficult because there is no job here. There's no money to buy food, to pay rent and other things like buy food for family."

On average the research data shows that in a "bad" month the day labourers at the hiring site in Parow earn R1375.00 (94,6USD) for the month while they can earn on average R3560.00 (245USD) when it is a "good" month. The income in a "good" month is equal or just above the South African accepted minimum wage of R3500 (240,8USD) per month, introduced on 1 January 2019, while the income for the "bad" month is only $39 \%$ of the accepted minimum wage.

One of the day labourers also added that it is a challenge that they are not able to choose the type of work they would prefer. They need to take what they are hired for: "I can do any job that is giving me money. I don't choose because if l choose work l will not find money."

Out of desperation they will take on any job, even if they are not necessarily qualified to do the work. This will be discussed in the next sub-theme.

\section{Sub-theme 2: Factors and considerations which motivated the participants to persist trying to obtain employment as day labourers}

The participants cited several different reasons for continuing to come to the hiring site in an attempt to obtain employment, despite the risks this entailed for them. Kerr and Dole (2001) maintain that in many instances day labourers accept the risks which their work entails owing to the pressures which are exerted by socioeconomic factors such as poverty and unemployment. Nevertheless, the authors endeavoured to establish why day labourers continued to gather at the hiring site in the light of their claims concerning the scarcity of opportunities for employment as seen in the previous sub-theme. The following statements provide relevant insights into the main factor which motivated the participants to 
keep returning hopefully to the hiring site almost every day, not knowing whether they will be able to access work:

"You know, the thing is most of us, we come here because we want to feed our families back home. We have dependents back at home, but since we do not have work there is nothing we can do. This is the place to look for work."

In response to the question of how they manage to survive on so little and manage to support dependants, one stated:

"We live within our means. What I am basically doing is to make sure at the end of the month I have enough money for rent and for food."

Theme 1 shows the forces, such as their sense of responsibility towards their families, that drive the day labourers to look for work, not knowing whether they will access any work.

\section{Theme 2: Forms of discrimination to which day labourers are subjected}

Two forms of discriminatory experiences were highlighted by the participants.

\section{Sub-theme 1: Discrimination amongst the day labourers}

According to Hepworth, Rooney, Rooney, Strom-Gottfried \& Larsen, (2010), discrimination is manifested in prejudicial attitudes, actions or treatment. Potgieter (1998) characterises discrimination as acting negatively towards others on the basis of their ages, languages, races, social classes, or cultures. It was found that discriminatory behaviour among the participants tended to stem from different national identities and home languages, mainly due to the fierce competition for work. The participants explained that they formed groups according to their home countries, as it was evident from the segregation of South Africans and Zimbabweans at the hiring site.

The three comments below illustrate the points raised in this section.

"The thing we going to do first, I am going to take the people I know. It is not my friend or friend or it is family, but I am going just pick up the people that I know first to communicate that there is work. I cannot just take the people who are not in my group because they are not like us."

"I will start with the bad, bad side. The first thing is discrimination, like some of us guys are foreigners. So the local people, some of them they might not be happy that foreigners are coming here to participate and give them competition for the same job. So on that side it is always discrimination, they try to fight you, they try to cause conflict and things like that."

"And also at some point where I go to work, which we get to work with the South African guys, they used to classify us and it is hard for us to be just taken as foreigners."

Blaauw et al. (2012) and Theodore et al (2018), concluded that immigrants are often among the most vulnerable members of any society. According to Deumert, Inder and Maitra (2005: 304), foreigners are effectively uncoupled from the social support structures and traditional safety nets which had been available to them in their home countries. The findings by Blaauw et al. (2012), Theodore et al (2018) and Crush, Chikanda \& Skinner, (2015) suggested that they are frequently exposed and subjected to vociferous and vindictive expressions of racism, xenophobia and other forms of discrimination in South Africa. As Pringle (2010) observes, these tendencies often become increasingly pronounced in times of economic downswings and the escalating levels of unemployment which result from these fluctuations in the business cycles in the countries to which foreign immigrants have been attracted.

\section{Sub-theme 2: Discrimination at the hands of employers}

The responses to the question how the participants are treated by employers, a variety of responses were shared ranging from:

"They treat me well because I know my job." 
"Some are good and some are bad."

"Once had an employer who ran away and did not pay for work done."

In addition participants reported that employers subjected day labourers to discrimination, particularly with respect to differential rates of remuneration. Similar findings were generated by the study conducted by Blaauw et al. (2016) in Cape Town, in which one of the day labourers whom they interviewed maintained that there were significant differences in the wages which employers paid day labourers, which appeared to be determined by the racial and social groups to which employers belonged.

One of the participants, this study explained:

One of the participants in this study stated:

"There is a struggle to get a job. Then there is an issue of race, you do not get paid the same."

It appeared that discrimination against foreign workers, particularly those who did not possess the necessary legal papers in the form of work permits or documents to confirm their asylum status, was often extremely severe as a Zimbabwean participant explained:

"In this place I find there is too little work, there is not too much. So if you get a job here, the boss, if they see you they do not have the papers, after the work they do not give you R100 or even $R 25$, because you do not have papers."

"The other problem we face here is when the guys who hire us for employment, they take us for granted because we are foreigners, but local South Africans [day labourers] think that we are favoured to get work and we steal their jobs."

There appears to be a fairly general consensus among researchers that the claim that South African workers are being driven out of the informal labour market by influxes of foreign immigrant workers to South Africa needs deeper investigation and evaluation (Blaauw et al ., 2012, Theodore et al 2018). In this study the average income in a 'good' month of the local day labourers were given as R3129.00 (215USD) while the average income in a 'good' month of the foreigners were given as R4783 (329USD). It should also be taken into account that all foreigners at the Parow site completed their schooling which is not the case of the South African counterparts and may be one of the reasons for being favoured to be hired for the day. As in the study by Blaauw (2010) the results contradicts the notion that the foreigners are paid less than the South Africans..

\section{THEME 3: THE RISKS WHICH THE WORKING CONDITIONS OF DAY LABOURERS ENTAIL}

One of the greatest risks the participants mentioned was that they do not know where and how they will work when they accept working for an unknown employer.

"So we are also exposed, we do not have that kind of protection, so they can take us to wherever they want to take us and they can do whatever they want to do with us."

Another referred to the risk of physical or verbal conflicts, particularly when foreign workers were obliged to mix with South Africans at workplaces, as explained by a Zimbabwean participant:

"You know how it is at the workplaces: sometimes we get mixed with the locals here. Some of the locals they do not like us to be at the workplace because they feel that we compete with them for the jobs. So at the workplace there can be some fights that are going to erupt or exchanges of words."

At the hiring site the foreigners and local day labourers are able to stay out of each other's way, but at work this is not possible and, according the participant:

"So at the workplace there can be fights and the boss will not speak." 
They cannot rely on the employer for protection.

Further risks highlighted relate to the absence of appropriate safety regulations:

"The other thing is, at the workplace there are no safety regulations that are being followed. So we just work there, not being protected from job injuries. When you are injured, you are not covered, you cover it at your own expense."

A participant complained that some of the employers do not give breaks, even for lunch, and that employers did not appreciate their hard work:

"Sometimes there is no break, there is no lunch. We work overtime and if you work overtime they do not recognise it and they do not appreciate our effort."

Malinga (2015) maintains that day labourers are always at great risk of being exploited by employers because they are in informal employment, desperate to earn money and without protection. Blaauw (2010) makes a similar assessment by contending that day labourers are often overworked and underpaid, or not paid at all.

The findings further revealed that on difficult days, when opportunities for employment were scarce, some of the participants had been sufficiently desperate to be prepared to accept a wage of as low as R30 a day. By contrast, days which they considered to be 'good' days could yield wages in excess of $\mathrm{R} 1,000$ for certain highly skilled tasks such as painting or tiling. The following comments were shared by the participants:

"We take any amount, especially when it is towards month-end, because we want to pay rent and buy food."

"I take any amount, even R50 to buy bread, so that l can be able to work tomorrow."

"Half a loaf is better than nothing, so if there are no jobs, we take any amount."

All of the excerpts demonstrate the vulnerability of day labourers regarding not being able to bargain or negotiate their wages with employers at times. If they are desperate, they take the amounts which are offered.

\section{Theme 4: The risks to which day labourers are exposed in relation to inconsistent earnings and non-payment of wages}

Inconsistent earnings tend to represent a burden for day labourers throughout the world. Blaauw et al. (2006), Louw (2007) and Blaauw (2010) found inconsistency in the wages which employers paid to day labourers, which accorded with the findings of this study in this respect. Not knowing that you will have sufficient funding by the end of the month places severe levels of stress on the day labourers as they fear that their families will face the consequenceses.

One participant explained:

"The next thing is the inconsistency, like sometimes you get picked once or twice or three times a week. It is not always that you go there and find a job. You go there for nothing, because they do not pay and your bills never stop coming. You must pay rent at the end of the month. You must do something, if you got kids back home, your family they all depend on you, but you are not consistently working, and you work once or twice in a row."

The data from the questionnaires show that the day labourers in Parow can earn on average R1,375 in a "bad" month while a "good" month can yield and average of R3,560.

The interviews also highlighted that the participants often did not negotiate for wages, owing to fierce competition for the work which became available. Van Breda (2014), a researcher in the field of resilience among the youth and children, emphasises the necessity of young men who seek employment being able to navigate the social processes which negotiating wages entails. The following comment 
provides a compelling elucidation of the consequences which can result from unsatisfactorily concluded negotiations for wages:

"Yeah, they(the family) say you must go, you are not working. Kanti funeka ulinde imali ayipeyayo phaya emlungwini ngoku umlungu uthi khange utsho ukuba uzokhetsha imali. Ngoku kunzima ukuna ndikunike imali ndingakunika imbahla, mhlawbi ndizokunika xa usebenzile, kubonakala ba usebenzile. Ugqiba kwakho ke." [You have to wait for him to pay you, but he will claim that you didn't say that you wanted money and end up giving me clothes. And I went with someone who said to me 'I cannot give you money now, maybe I will give it to you when I am satisfied with your work'.]

Other responses revealed that the amounts the day labourers are paid, failed to match the amounts which had been cited during the brief interactions with employers at the hiring site. Although it also needs to be emphasised that wages tend to vary according to the types of work which day labourers are required to perform, in this case the participants complained that their wages for performing the same types of work also tended to vary considerably. Camou, (2009) maintains that day labourers often accept employment without having sufficient information concerning prospective employers, which results in their being subjected to abusive behaviour such as non- or under-payment of wages. Conversely, both Blaauw et al. (2006) and Theodore et al. (2015) suggest that even if there are negotiations between employers and day labourers, they do not necessarily guarantee that the day labourers will be paid for the work which they have performed. The following excerpts serve to illustrate the findings pertaining to this theme:

"Yeah, it depends on the type of work but basically it ranges from R150 to R200 (per day)."

"Sometimes they pay a small amount, maybe R60, and the type of job that we do is hard, you know."

"I think one of them is that if you find someone to go and work with, you are going to face the problems that I do and not get the real money I am supposed to get. Some of them are going to give you the money that they want to give you ... Like 10, 20 or 50 rand."

On the question of whether they have ever turned down a job, 45,8\% answered positively, giving the reason that "the pay was too low". The attitude of the employers also played a role in their turning down jobs if the employer is known to the day labourers.

\section{Theme 5: The resilience which day labourers display}

One of the major processes towards maintaining resilience is in the support which the day labourers provided to one another. Neimeyer (1994) contends that people endeavour to construct events and occurrences which they experience in order to be able to anticipate similar events in the future. It is highly likely that if day labourers were to anticipate unpleasant or demeaning experiences, their resilience could be negatively affected as a consequence. It was evident from the responses of the participants that mutual support represented a vital means of coping with the stresses and anxieties which they encountered in their daily lives. Of the 24 participants, $15(62,5 \%)$ indicated that they are part of a group who support each other as day labourers. One of the participants, explaining how they took care of one another in the event of injury, said:

"We just take him, as a friend, we just take him and call his neighbours or relatives, then you take him to hospital or call an ambulance, then take him to hospital."

Other relevant comments included:

"We can also help each other to find work. Let's say, for example, someone is hired by a construction company, then the owner of that construction company wants some more guys."

"Okay, as Zimbabweans we understand each other, where we come from. That is why we usually come together so that we can find some work. We do not come here as friends, we just 
come closer because we support each other and we speak the same language, then we start to look for jobs."

One participant also explained that knowing people or having friends who were in full-time employment often facilitated obtaining work for them as day labourers. The mutual support which day labourers frequently give one another was also borne out by the findings of the national study by Blaauw (2010), which revealed that day labourers supported one another in times of need when fellow day labours experienced privations such as being unable to pay for transport, having no food to eat, or lacking shelter.

\section{Sub-theme: Resilience owing to support received in their broader contexts}

Communities, churches and benevolent organisations all play crucial roles in human development and survival (Nattrass, 2002). The participants reported that they received support from churches, members of their own communities, relatives and well-meaning people in the community around the hiring site. There appeared to be a general consensus among the participants that the assistance was beneficial and helped them to avoid succumbing to feelings of despair.

In the words of the participants:

"Yeah, sometimes I struggle to find that money and sometimes my relatives they help me to raise up that amount."

"I used to borrow from some people so is just living without ... End of the month you just find out you have nothing and you ask other friends to help."

"We do survive from handouts, people giving us bread and, if we are lucky, some cool drinks. Hope you going to buy one for us too."

"I think that is how we do survive, like we do survive from handouts, like churches come with food here and some clothes, but not every time ... Actually if you do not have work, life is tough because you just come here to look for handouts."

The responses confirmed that day labourers received assistance in the form of food and clothes, and the positive attitude of the public is appreciated and needed. The difference support from civil society can make in the lives of vulnerable people was also in the study by Rooderick, Blaauw and Schenck, (2016).

\section{DISCUSSION}

The continuous risks to which the day labourers were exposed in relation to obtaining employment and generating income had two components, namely, a frequent lack of employment, and their dogged persistence in a market which they themselves perceived to offer few opportunities for gainful employment. The theme of discrimination revealed that although day labourers are often subjected to severe discrimination and stigmatization at the hands of other day labourers and employers, some also practice intense discrimination themselves. In the latter case, it often takes the form of vociferous and sometimes violent expressions of xenophobia and racism against foreign workers, whom they perceive to be 'stealing' their opportunities to find employment. The resentment which they express is often fuelled by feelings of frustration and envy, because employers tend to prefer foreign workers owing to their superior qualifications and ability to speak English. It was found that the risks to which day labourers are exposed owing to their working conditions stem from the unregulated nature of the day labour market, as it is impossible to enforce the kinds of regulations that are adhered to in the formal sector in relation to payment and the health and safety of workers. The final theme which emerged concerning the risks they face concerned the pronounced inconsistency in the amounts of money which they were able to earn and the constant threat of either being underpaid or not paid at all by employers.

On the other hand, the results also show us how the day labourers skilfully evince resilience in managing their persistent poverty and adverse circumstances. It is impressive to see how they go to the 
hiring site 6 to 7 days a week in the hope that they might get work, and how they continue to travel long hours and distances to get to work either to find no work at all or be underpaid, or the odd times when they may get paid better than expected.

The implicit results show us that a few processes or drivers facilitated the resilience of the day labourers:

- Connections: Relationships with families, other day labourers and the people in their communities motivates them to continue - even it is the handouts;

- Hope: The day labourers go to the hiring site every day in the hope that there will be work and income, and maybe even access to formal regular work.

The findings of the study revealed that although some day labourers are highly skilled, skills do not necessarily enable them to earn adequate incomes or to enjoy a decent standard of living. Consequently, policies which are implemented solely to increase the skills levels of day labourers and other informal workers may not provide a sufficiently efficacious remedy for their inability to earn adequate incomes. Appropriate recommendations would include the development of overall frameworks to increase incomes through the acquisition of relevant skills, the promulgation of mandatory health and safety regulations for all employers, and measures to promote and maintain environmental health.

Those who are tasked with the formulation of policy would be well advised to investigate the feasibility of adopting the worker-centred model, which has been used successfully in countries such as the United States. The application of the model should not only provide a formal structure to provide day labourers with the means to hire themselves out on equitable terms, but also to provide appropriate regulatory mechanisms to ensure that the rights of informal day labourers accord with those of workers who are employed in the formal sector. Adequate regulation would contribute significantly to precluding day labourers from being underpaid and overworked, and also to ensuring that their working conditions comply with national standards for the formal sector. This regulation of the day labour market could be further formalised by requiring both day labourers and potential employers to be officially registered. In South Africa interventions in day labour markets were coordinated by Men on the Side of the Road (MSR), a social enterprise organisation which was founded in in Cape Town in 1999 and has affiliates in other parts of the country. In addition, it has been reported that MSR endeavoured to increase the skills of day labourers, through in-service training and developing procedures for enabling employers to evaluate the skills of workers. However, recent indications are that MSR has ceased operations. The need to certify the skills of workers in the informal economy has been recognised in relevant literature (Revell, 2010).

There is considerable evidence to suggest that day labourers who negotiate their wages and have a reservation wage are more likely to earn high wages than those who do not. Consequently, interventions which are based upon the worker-centred model to regulate the informal day labour market could entail the setting of minimum wages in accordance with the skills which day labourers possess. Obliging registered day labourers to attend workshops which provide training and opportunities to upgrade their skills on days on which they are unable to find employment would significantly increase the probability of their securing permanent formal employment in the future and also increase the frequency with which they are hired.

There can be little doubt that opportunities for employment for day labourers would increase dramatically if the government were to offer segments of the formal sector, such as the construction industry, incentives such as tax rebates or financial assistance to hire registered day labourers who possess the skills which they require. Appropriate strategies would contribute significantly to fulfil the urgent priorities of the government to reduce unemployment and create employment. 


\section{CONCLUSION}

Day labourers respond better than expected to adversity due to the hope they live on and the support they receive from those around them. The results provide a clear direction to social service professionals which services to put in place, such as the creation of supportive conditions at the hiring sites and the facilitation of caring communities. It is further important to support enhancement of skills and access to food, facilities, health services and advocacy services. A big concern remains the consistent theme of conflict between the local and foreign day labourers, which is built on myths and misconceptions. We need to engage with the day labourers on the street to hear their voices, concerns, risks and insecurities to enhance the relationships amongst the day labourers, the day labourers and the employers and the communities where they stand. Day labouring will not go away as long as it provides an opportunity for hope. Enhancing their resilience will enable them to be better providers for their families and communities.

\section{REFERENCES}

BABBIE, E. \& MOUTON, J. 2008. The basics of social research. $\left(4^{\text {th }}\right.$ ed). Belmont: Thomson Wadsworth.

BABBIE, E. \& MOUTON, J. 2010. The Practice of Social Research. Cape Town: Oxford University Press.

BLAAUW, P.F., LOUW, H. \& SCHENCK, C.J. 2006. The dynamics of informal labour markets in South Africa. A case study of day labourers in Pretoria. Department of Economics Research Paper No. 0501, University of Johannesburg.

BLAAUW, P.F. 2010. The socioeconomic aspects of day labouring in South Africa. Johannesburg: University of Johannesburg. (DCom thesis)

BLAAUW P.F, PRETORIUS A.M, SCHOEMAN C.H \& SCHENCK C.J 2012. Explaining migrant wages: The case of Zimbabwean day labourers in South Africa International Business and Economics Research Journal. 11(12):1333-1346.

BLAAUW, D., PRETORIUS, A., \& SCHENCK, C.J. 2016. Day labourers and the role of foreign migrants: For better or for worse? [Online] Available: Econ $3 \times 3$ http://www.econ3x3.org/article/day-labourers-and-role-foreign-migrants-better-or-worse [Accessed 26/10/2018].

BLAAUW, P.F., SCHENCK, C.J., PRETORIUS, A.M. \& SCHOEMAN, C.H. 2017. 'All quiet on the social work front': Experiences of Zimbabwean day labourers in South Africa. International Social Work, 60 (2), 351-365.

BLESS, C, HIGSON-SMITH, C., \& HAGEE, A. 2006. Fundamentals of Social Research Methods: An African Perspective. $\left(4^{\text {th }}\right.$ ed). Cape Town: Juta.

BRAUN, V. \& CLARKE, V. 2006. Using thematic analysis in psychology. Qualitative Research in Psychology. 3(2), 77-101.

CAMOU, S. 2009. The underemployed: Evidence from the UK labour force survey. Cardiff School of Social Sciences Working Paper Series, Paper no.152. Cardiff: School of Social Sciences.

CRUSH, J., CHIKANDA, A., \& SKINNER, C. 2015. Mean streets: Migration, xenophobia and informality in South Africa. Cape Town: Southern African Migration Programme, African Centre for Cities, and International Development Research Centre.

DEUMERT, D., INDER, Y. AND MAITRA, J. 2005. The social costs of underemployment: Inadequate employment as disguised unemployment. New York: NY: Cambridge University Press.

DE VOS, A., STRYDOM, H., FOUCHE, C., \& DELPORT, C. 2011. (4 ${ }^{\text {th }}$ ed). Research at Grass Roots for the Social Sciences and Human Service Professions. Pretoria: Van Schaik. 
DUBBELD, B. 2013. How social security becomes social insecurity: Fluid households, crisis talks and the value of grants in a Kwa-Zulu Natal village. [Online] Available: https://wiser.wits.ac.za/system/files/seminar/Dubbeld2013.pdf [Accessed: 29/05/2019].

ERDOGAN, B., \& BAUER, T. N. 2009. Perceived over-qualification and its outcomes: The moderating role of empowerment. Journal of Applied Psychology, 94(2), 557-65.

GEERTZ, C.1973. The interpretation of cultures (Vol. 5019). New York. Basic books.

HAMMERSLEY, M. \& ATKINSON, P. 1983. Ethnography: Principles in practice. London: Tavistock.

HEPWORTH, D.H., ROONEY, R.H., ROONEY, G.D., STROM-GOTTFRIED, K. \& LARSEN, J. 2010. Direct social work practice: Theory and skills, $\left(8^{\text {th }} \mathrm{ed}\right)$. Belmont: Cengage Learning.

HOEY, B. 2014. System and methods for real-time detection, correction, and transformation of time series data. IFI CLAIMS Patent Services.

INTERNATIONAL LABOUR ORGANISATION (ILO) 2005. World employment report 2004-05: Employment, productivity and poverty reduction, Geneva: International Labour Office.

KERR, D. \& DOLE, C. 2001. Challenging exploitation and abuse: A study of the day labor industry in Cleveland City Council. Unpublished report for the Cleveland City Council, Cleveland, USA.

KOK, P., CROSS, C. \& ROWE, N. 2010. Towards a demographic profile of the day labourers in South Africa. Development Southern Africa, 27(1):21-37.

LOUW, H. 2007. Men at the margins: Day labourers at informal hiring sites in Tshwane, University of South Africa. Pretoria: (PhD-thesis)

MALINGA, M.V 2015. Precarious employment and fathering practices among African men.. University of South Africa. Pretoria: (DPhil thesis)

MOBERLY, R 1987. Temporary, part time and other atypical employment relationships in the United States. Labor Law Journal, 38:689-696.

NATTRASS, N. 2002. Unemployment, employment and labour-force participation in Khayelitsha/Mitchell's Plain. Cape Town. Centre for Social Sciences Research. Working Paper No. 12.

NEIMEYER, R.A. 1994. Validity and reliability of the multidimensional fear of death scale. California: Taylor \& Francis.

PECK, J. \& THEODORE, N. 2001.Welfare to work in America: Searching for best Practice in Welfare-to-work: The means, the method and the message. Policy \& politics, 29(1):81-94.

POTGIETER, M.C 1998. The Social Work Process: Development to Empower People. Prentice Hall South Africa (Pty) Ltd.

PRINGLE, K. J. 2010. The global distribution of the effective aerosol hygroscopicity parameter for CCN activation. Atmos. [Online] Available: https://doi.org/10.5194/acp-10-5241-2010, 2010. [Accessed 26/09/2018].

REVELL, K 2010. Working with informality: Increasing resilience in cities of the Global Southern Africa. Canage: Sage Publications.

ROODERICK M., BLAAUW P F AND SCHENCK C J 2016. The economic impact of NGOs on the well-being of extended households in Soweto The Social Work Practitioner-Researcher, 28 (3): 221235. 
STERKEN M. 2010. The flexibility of recruitment in the construction industry: Formalisation. Sociology (19): 108-124.

THEODORE. N, BLAAUW, D., SCHENCK, C.J., VALENZUELA, A. JR, SCHOEMAN. C., \& MELÉNDEZ, E. 2015. Day labour, informality and vulnerability in South Africa and the United States. International Journal of Manpower, 36(6): 807-823.

THEODORE N, PRETORIUS A, BLAAUW D, SCHENCK C. 2018. Informality and the context of reception in South Africa's new immigrant destinations. Population, Space Place. [Online] Available: https://doi.org/10.1002/psp.2119. [Accessed: 25/05/2019].

TRIMBLE, J.E. \& FISHER, C.B. eds., 2006. The handbook of ethical research with ethnocultural populations and communities. Thousand Oaks. Sage Publications.

VAN BREDA, A.D. 2014. Validation of a measure of resilience of youths exiting residential care. Unpublished document. University of Johannesburg, Johannesburg, RSA. [Online] Available: https://www.girlsandboystown.org.za/wp-content/uploads/2017/08/Van-Breda-2014-Validation-of-ameasure-of-resilience.pdf [Accessed 14 April 2019].

VAN BREDA, A.D.2018. A critical review of resilience theory and its relevance for Social Work. Social Work/Maatskaplike Werk. 54(1): 1-18

WALKER, B. H., ANDERIES, J. M., KINZIG, A. P., \& RYAN, P. 2006. Exploring resilience in social-ecological systems through comparative studies and theory development: Introduction to the special issue. Ecology and Society, 11(1): 12.

WORTHINGTON, E.L. and SCHERER, M., 2004. Forgiveness is an emotion-focused coping strategy that can reduce health risks and promote health resilience: Theory, review, and hypotheses. Psychology \& Health, 19(3): 385-405. 